\title{
A Modified Elastic Calculation Method Of Ground Surface Settlement Induced By Dewatering In Foundation Pit
}

\author{
a Jian Tang, bLang $\mathrm{Wu},{ }^{\mathrm{c}}$ Ying Huang \\ aJian Tang, College of Civil Engineering, JiangXi Science\&Technology Normal Univercity, Jiangxi \\ Nanchang, China \\ ${ }^{b}$ College of Civil Engineering, Nanchang Institute of Technology, Jiangxi Nanchang, Chin \\ 'Ying Huang, College of Civil Engineering, JiangXi Science\&Technology Normal Univercity, Jiangxi \\ Nanchang, China
}

KEYWORD: Foundation pit; Elastic Calculation Method

ABSTRACT: This paper firstly summarized layering summation method which have been widely applied in calculating settlement of ground surface induced by dewatering in foundation pit, and then analysis the problem the method exist and put forward a new formula that embankment with pore through rate, which based on original method by using mathematical analysis. At last, Take the project of dewatering in foundation pit where lies in HanJiang area, PuTian city, FuJian province as example, the author have compared the result by using the original method and the method this paper proposed and made some important conclusions.

\section{INTRODUCTION}

The settlement induced by dewatering in foundation pit have been always a heated and complicated problem in the foundation engineering field.There are many researchers and scholars at home and abroad have been taking a lot of research on the settlement induced by dewatering in foundation and proposed some calculation method:Wu Gaoling ${ }^{[1]}$ proposed a method that based on viscoelastic theory to calculate ground surface settlement,which the principle is to calculate settlement through the vertical compressive displacement of soil skeleton that have two aquifers;T.M Sharansky ${ }^{[2]}$ have mentioned the method by using soil additional stress which firstly analysis soil skeleton stress distribution law of before and after dewatering, and then calculate settlement ; There is also a method in engineering to calculate ground surface settlement by means of measuring the settlement when the compression thickness is $1 \mathrm{~m}$ and head aquifer changes is $1 \mathrm{~m}$; Some scholars proposed to calculate ground surface settlement by using the method of "free water loss calculation", which obtain the water volume.Because in these method some are too complicated,or some are imprecise because of only basing on estimation, the layering summation method that based on elastic theory is widely applied in the project,which the principle is first to assume the soil layer in the scope of compression have no lateral expansion, and then divide the soil layer into several thicker layers in principle of soil mechanics mentioned, calculate the settlement of the point on the central axis, lastly summarize the settlement, the result as the final settlement.The essentials of this method is clear,and consider more factor, so this method is widely applied in the project.

\section{THE GROUND SURFACE SETTLEMENT CALCULATION METHOD BASED ON ELASTIC THEORY}

In the introduction the author have mentioned that the layering summation method is a clear method to calculate settlement of ground surface induced by dewatering in foundation pit. The reason why the sum of elastic deformation method can be used to calculate the final settlement is not only that the distribution law of pore water pressure under the one-dimensional consolidation conditions is very similar to the theory line of Terzaghi one-dimensional consolidation equation,but also that the degree of consolidation is almost identical.

The calculation for clayey soil layer 
(1)First analysis the layers structure in the scope of settlement,determine the settlement layers and stable layers according to geological exploration data;

(2) Select the appropriate flow formula to calculate the groundwater levels at different times and rendering time groundwater level change curve;

(3) Calculate the final settlement of each the difference for groundwater level;

(4)Calculate the settlement $S_{t}$ when under the effect of each water level difference (stress increment)

(5) Summarize the the former result according to time sequence, which is the total settlement during this time, and draw the settlement - time curve .

Hysteresis effect need not to consider because the sand layer have well water permeability and can finish deformation within short time.

\section{MODIFIED CALCULATION METHOD OF GROUND SURFACE SETTLEMENT BASED ON ELASTIC THEORY}

\section{Questions in layering summation method based on theory}

If the spatial and temporal distribution characteristic of additional stress increment when water head rise and fall could be obtained exactly,the calculation settlement induced by dewatering in foundation pit would be solved easily. However,the formula to calculate additional stress increment. Two problems concerning the method based on elastic theory are pointed out :

(1)According to the analysis on effective stress of dewatering in foundation, when the groundwater is diving,there are two main situations :one that diving have no pressure whether dewatering,part of aquifer draining because of the falling induced by dewatering;one that diving have pressure before dewatering,the water head lower than the aquifuge roof,part of aquifer draining,the diving become into have pressure. The two situation make the calculation for soil additional stress relatively conserve.

(2) The current calculation methods are too complicated, and the results have larger error.

\section{Modification for the calculation method res}

The total stress changes always occur in the clay layer when determining additional load induced by dewatering. Currently when determining the additional stress induced by dewatering the fact that the gravity water in the pore under the closed state could not pass hydrostatic pressure in the clayey soil layer and only the gravity water in the pore under the opened state could pass hydrostatic pressure have not been taken into account.

Meanwhile, in order to simplify the calculation process to reduce errors, according to the effective stress increment of soil to calculate settlement induced by dewatering.Model can be established as shown in Figure1,for the dewatering and drying layer that effective stress changes.

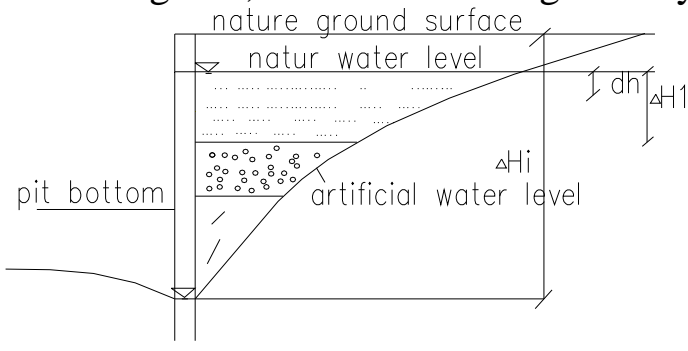

Figure1 settlement calculation model

\section{ENGINEERING APPLICATIONS FOR MODIFIED CALCULATION METHOD}

\section{Project Overview}

The foundation pit engineering lies between 244\# piers and 245\# piers of high speed railway bridge Putian,which is rectangular and its length is $25 \mathrm{~m}$,width is $10.2 \mathrm{~m}$;depth is about $10.8 \mathrm{~m}$.Its east and 
west sides are two piers, on the north side is the open space, on the south side is the road,as the figure2 shows:

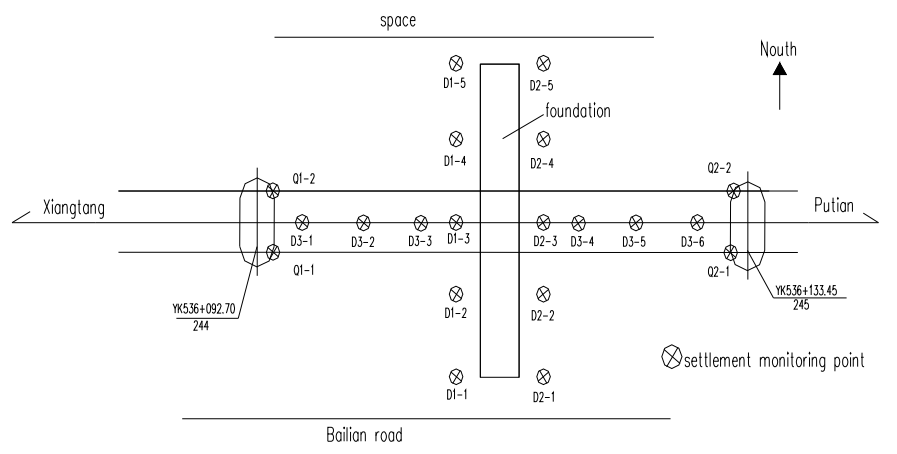

Figure2 mPit plane and subsidence monitoring points schematic arrangement

The surface fill of the site have been excavated Artificially, the depth of diving static water level is $2 \mathrm{~m}$,soil layers around the foundation shows in table 1 :

Table1 Geological conditions

\begin{tabular}{|c|c|c|c|}
\hline $\begin{array}{l}\text { Soil } \\
\text { name }\end{array}$ & Soil characteristic & $\begin{array}{l}\text { Aver- } \\
\text { age } \\
\text { thick- } \\
\text { ness/m }\end{array}$ & $\begin{array}{l}\text { Permea- } \\
\text { bility } \\
\text { coeffi- } \\
\text { cient } / \mathrm{m} / \\
\mathrm{d}\end{array}$ \\
\hline $\begin{array}{l}\text { Silty } \\
\text { clay }\end{array}$ & $\begin{array}{l}\text { Uneven,Sandwiching a thin } \\
\text { layer of sandy silt and silty } \\
\text { clay lenses }\end{array}$ & 4.57 & 0.2 \\
\hline $\begin{array}{l}\text { Fine } \\
\text { sand }\end{array}$ & $\begin{array}{l}\text { Sand impure,Local } \\
\text { silt,Containing a small amount } \\
\text { of clay soil clumps, Top cov- } \\
\text { ered with discontinuous sandy } \\
\text { silt }\end{array}$ & 3.00 & 5.0 \\
\hline $\begin{array}{l}\text { Dens } \\
\text { e } \\
\text { Peb- } \\
\text { ble }\end{array}$ & $\begin{array}{l}\text { Saturated,The upper clip a few } \\
\text { round gravel, The lower part } \\
\text { pebble, Pebble particle size is } \\
\text { generally } 3-6 \mathrm{~cm} \text {, Filled with } \\
\text { fine sand }\end{array}$ & 4.77 & 100 \\
\hline $\begin{array}{l}\text { Silty } \\
\text { clay }\end{array}$ & $\begin{array}{l}\text { Uneven,,Sandwiching a thin } \\
\text { layer of sandy silt, heavy } \\
\text { silty clay and Sandy silt lenses }\end{array}$ & 5.90 & 0.1 \\
\hline
\end{tabular}

\section{Settlement Calculation}

This project uses the pipe well to dewater,the calculation for settlement of piers foundation induced by dewatering is based on the design calculation of foundation dewater,calculated according to the following parameters: the radius $\mathrm{R}=69 \mathrm{~m}$, which affected by dewatering, the height of the diving aquifer $\mathrm{H}=16 \mathrm{~m}$, the foundation drawdown value $\mathrm{S}=11.05 \mathrm{~m}$. For the theoretical calculation with the observed values form valid comparison, this paper choose four monitoring points D2-3,D34,D3-5,D3-6 which near to far from pumping wells as calculated point (Figure 2), above-mentioned four point to pumping wells distance separately are $6 \mathrm{~m}, 12 \mathrm{~m}, 17.5 \mathrm{~m}, 22 \mathrm{~m}$.Each point drawdown as shown in Table 2: 
Table 2 the water level drop depth of each monitoring point

\begin{tabular}{c|c|c|c|c}
\hline $\begin{array}{c}\text { Dewatering } \\
\text { point }\end{array}$ & $\begin{array}{c}\text { D2- } \\
3\end{array}$ & $\begin{array}{c}\text { D3- } \\
4\end{array}$ & D3-5 & $\begin{array}{c}\text { D3- } \\
6\end{array}$ \\
\hline $\begin{array}{c}\text { Distance } \\
(\mathrm{m})\end{array}$ & 6 & 12 & 17.5 & 23 \\
$\begin{array}{c}\text { Drop depth } \\
(\mathrm{m})\end{array}$ & 8.24 & 7.21 & 4.10 & 1.78 \\
\hline
\end{tabular}

As shown in Figure 3,there are three soil layers within the scope of the soil drawdown of the four point D2-3、D3-4、D3-5、D3-6, The parameters show in the table3:

\section{ACKNOWLEDGEMENTS}

This work was financially supported by the Natural Science Fund project in Jiangxi province (20161BAB206148), and Science\&Technology Project Founded in the Department of Jiangxi Province (GJJ151173), and the key research topic of JiangXi Science\&Technology Normal Univercity (300098010502).

\section{REFERENCES}

[1]Ikegami, R., D. G. Wilson, J. R. Anderson, and G. J. Julien. 1990. “Active Vibration Control Using NiTiNOL and Piezoelectric Ceramics,” J. Intell. Matls. Sys. \&Struct., 20(2):189-206.

[2]Mitsiti, M. 1996. Wavelet Toolbox, For Use with MALAB. The Math Works, Inc., pp. 111117.

[3]Inman, D.J. 1998. "Smart Structures Solutions to Vibration Problems," in International Conference on Noise and Vibration Engineering, C. W. Jefford, K. L. Reinhart, and L. S. Shield, eds. Amsterdam: Elsevier, pp. 79-83.

[4]Margarit, K. L. and F. Y. Sanford. March 1993. "Basic Technology of Intelligent Systems," Fourth Progress Report, Department of Smart Materials, Virginia Polytechnic Institute and StateUniversity, Blacksburg.

[5]Hoffer, R. and D. Dean. 1996. "Geomatics at Colorado State University," presented at the $6^{\text {th }}$ Forest Service Remote Sensing Applications Conference, April 29-May 3, 1996. 